Indonesian Journal of EFL and Linguistics

Vol. 4 No. 2, 2019

eISSN: 2503-4197, pISSN: 2527-5070

www. indonesian-efl-journal.org

\title{
The Correlation among English Learning Anxiety, Speaking and Writing Achievements of Senior High School Students
}

\author{
Dian Eva Lestari \\ English Language Education \\ Sriwijaya University \\ email: 1dian2627@gmail.com \\ Bambang Loeneto \\ English Language Education \\ Sriwijaya University \\ email: loenetobambang@gmail.com \\ Diemroh Ihsan \\ English Language Education \\ Sriwijaya University \\ email:diemroh.ihsan@facebook.com
}

\begin{abstract}
:
The objectives of the study were to analyze whether or not there were a significant correlation among English learning anxiety, speaking, and writing achievements of the eleventh graders'. The sample of the study were 112 eleventh graders'. They were selected randomly. The study used quantitative research design. The questionnaire and the writing and speaking tests were done to analyze the data. The researcher used foreign language classroom anxiety scale questionnaire to measure the students' English learning anxiety with five-point likert scale, and speaking and writing tests were used to measure the students' speaking and writing achievements. Pearson product moment correlation and regression were analyzed by using SPSS.
\end{abstract}


Dian Eva Lestari, Bambang Loeneto and Diemroh Ihsan

The results of study were negative low correlation between English learning anxiety and speaking achievement ( $r=-.269$ with $p<0.01)$ and English learning anxiety and writing achievement ( $r=-.213$ with $p<0.05$ ).

Keywords: English learning anxiety, speaking achievement, writing achievement

\section{INTRODUCTION}

English is as an international language because English achieves $80 \%$ of sites as medium language and $20 \%$ of others language. So, we can indicate that people can accept less than $20 \%$ of new knowledge, if the students do not use English as their second language, Alfitri (2012, as cited in Reddy, 2016). Kementrian Pendidikan dan Kebudayaan RI number 22 year 2016 states that English has four skills such as speaking, listening, reading, and writing. Among the four skills, speaking and writing are very important skills because they reflect what people do with a language. Writing is the basic skill that make the students to be imperative and effective writers (Emmos, 2003, as cited in Younez and Albalawi, 2015). While speaking is the productive skill and great significant way for people interaction to communicate ideas and messages orally (Gilakjani, 2016). Writing and speaking have relationship each other because speaking skill can produce some critical analysis. For example, the students adopt good plannings when exchange to write from instructing rhetoric of speaking, monopolize in writing from spelling and other conventions, and practice the premeditated can utilize the standard academic language model (Rausch, 2015).

English learning anxiety can be a complicated process which influences the students' academic achievements. One of factors can effect for the students' achievement especially in speaking and writing achievements is English learning anxiety because it recognizes as the mental block against and conceives the factors of the students' learning. English learning anxiety is the important role of individual characteristics that hampers the students' learning (Rischards, 2006, as cited in Fitriati and Jannah, 2016). The types of English learning anxiety are trait, state anxiety, and situation specific. English learning anxiety has relationship with the students' achievement. It gives positive and negative impacts for the students' achievement. Those phenomenas may happen because the students have facilitating and debilitating anxiety. According to Horwitz (1986, as cited in Gkonou, Daubney, and Dewale, 2017) reported that the correlation of negative versus positive can generate facilitating versus debilitating role of English learning anxiety. According Kruk's (2018) investigated 52 Polish senior high school students by using questionnaire, interview, and lesson plans. The findings found that English learning anxiety can change the students' learning from one language lesson to others either along semester or during class. Despite negative effect of English learning anxiety, it also can give positive effect for the students' learning achievement. English learning 
anxiety gives motivation for the students to learn more and give advance for their performance. The researcher investigated $100 \mathrm{EFL}$ students in Malaysia University by using questionnaire (Selvam et al., 2016). Moreover, Ariyanti (2017) had done studies in Samarinda University states that the students achieved anxiety because the students wrote with limit time and lacked the inadequate capability to generate the ideas in English. Ushiba and Sano (2013, as cited in Kralova, 2016) also said that his oral proficiency had fossilized at much lower level than his writing proficiency. It is about $50 \%$ of the 50 participants felt anxious when they speak English while $18 \%$ felt anxious when they write in English. It means that the students' speaking ability are weak because there are $46,5 \%$ students who get double lower speaking skill especially in Indonesia. It can be proved that the students in Indonesia are low and difficult skills for the students (Mukmin et al., 2015). In relation speaking, the students get difficulties in mastering speaking English. Nguyen and Tran (2015) also stated that the students lack the knowledge, inhibition, low practice, and mother tongue for their daily communication in English. English learning anxiety occurs because students have different views, norms, and behavior patterns. For example, the students feel worry and fear among the learner during learning process. According to Seyitoglu, Guven, and Kocabulut (2015) stated that the students did not feel self-confidence, be shy to others, be afraid in making mistakes, nervousness, never practice with others, feel confused to say anything, and inhibit in speaking English.

The reseacher found some problems in writing and speaking skills by interviewing with the teacher of SMA Srijaya Negara Palembang. In writing, when the students wrote a word or a sentence, they beyond grammatically whether it is correct or wrong. They did not think that their writing are meaningful or not. The students also lack vocabulary because writing deals many different brain functions. For example, the students generate ideas, organize the right words in writing, understand and apply the grammar, spelling, or function. There are $49 \%$ of the students who get weak and substandard in writing. The students get the lack of confidence, syntactic, lexical and grammatical command (Dar and Khan, 2015). The students of SMA Srijaya Negara Palembang informed that they had limited ideas in writing because they lacked vocabulary to express their ideas and had limited language features. While in speaking skill, the students had limited vocabulary, got difficulty in delivering good grammar and in using appropriate words, and was shy to practice with others. Then, the students' competence (Kriteria Ketuntasan Minimum/KKM) of the eleventh graders' students must achieve the score of 67 in general. The average of students' writing and speaking achievements were about below 67 score, so the students' writing and speaking achievements still beyond from the National Standard School. Moreover, Kementrian Pendidikan dan Kebudayaan RI number 22 year 2016 (revision) about Process Standard including syllabus and lesson plan explained that exposition text, factual report text, and procedure text are taught in the eleventh graders' students of Senior High School in teaching English. The 
researcher chose the factual report text that is a kind of text types of writing that provides the information about something. The topics of factual report text can be a specific thing, human, animal, natural phenomena, and social phenomenon (Anwar and Iramawaty, 2015). Based on the explanation above, the aims of the study were to investigate whether or not there were a significant correlation among English learning anxiety, writing, and speaking achievements.

\section{LITERATURE REVIEW}

English learning anxiety is an individual characteristics which has an important role and of factors of element that hamper learning of foreign language especially in writing and speaking skills (Richards, 2016, as cited in Fitriati and Jannah, 2016). English learning anxiety can give positive and negative impacts. When the students feel anxious, they feel afraid to make mistake, shy, nothing to day or loss of ideas, so it can give significant effect for the students' achievement and develop uneasy behavior in speaking English (Sayuri, 2016). English learning anxiety is as the results structural inequality, performance, and commucation with others in the classroom.

According to Duraku (2017) explained that the causes of English learning anxiety are academic and stress factors. The academic factors defines that the pressure in achieving the appropriate results. For example, the students' knowledge, study skills, and etc. While the students' level of stress means what the students do that relate with psychological, financial, health problems, and other personal aspects. The students felt afraid, do not prepare well, have limit time, lack study skill, have responsbilities, and etc.

Achievement defines that the students' level of achievement such as knowledge, skill, and experience that can achieve the target of learning objectives in the school's curriculum. Indicator of achievements get by setting the standard value from each institution and changing the level of students in all academic subjects in the test and assessment (Firmander, Gavin, and McCouch, 2014). Writing and speaking achievements are the results of their performance in writing and speaking, so writing and speaking achievements are as the indicators to know what the students get in their speaking of learning. The achievements are designed in the score by teachers' marks.

According to Kementrian Pendidikan dan Kebudayaan RI number 22 year 2016 (revision) about Process Standard including syllabus and lesson plan expained that there were three terms of writing such as exposition text, factual report text, and procedure text which must be taught in the eleventh graders' students of Senior High School in teaching English. The researcher used the factual report text in the study. According to Anwar and Iramawaty (2015) described that factual report text is a kind of text types of writing that provides the information about something. The topics of factual report text can be a thing, human, animal, natural phenomenon, 
social phenomena, and etc. The language features of factual report text are : 1) the use of present tense, 2) the use of action passive voice, and 3) the use of descriptive but factual language.

Many researcher investigated the evidence of English learning anxiety which gives the significant influences on language learning. When the students are less anxious, they will show better in self-rated language proficiency (Dewale and Al-Saraj, 2015, students' English achievement (Gerencheal, 2016) and students' performance (Salehi and Marefat, 2014). English learning anxiety can give either positive or negative impacts for the students' achievement. Kruk's (2018) investigated 52 Polish senior high school students by using questionnaire, interview, and lesson plan. The study found that English learning anxiety can change and effect for the students' learning in the semester during class from one language lesson to others. On the other hand, English learning anxiety also give positive effect for the students' achievement. Selvam et al. (2016) investigated 100 EFL students by questionnaire in Malaysia University. The results of study found that the students were in moderate speaking anxiety. English learning anxiety motivated the students to learn more from their failure and give better performance. So, English learning anxiety reflects about the students' interest, the intellect of skills, and unexpected results.

Numerous study has found the strategies to reduce the English learning anxiety. Albarai (2015) divided three approaches in reducing English learning anxiety such as cognitive, affective, and behavioral as following:

1) Cognitive means how to change the students' own cognitive appraisals. The teacher can create some effective cooperative learning techniques. For example, playing language games with emphasis on problem solving, using role play, and etc.

2) Affective focuses on reducing negative effects of English learning anxiety experience and including therapies. For example, relaxion, recall techniques, biofeedback, support groups, and etc.

3) Behavioral means that English learning anxiety occurs as the results of the students' performance especially in speaking and writing. For example, computerized pronounciation practice, and teaching speaking in virtual environment.

\section{RESEARCH METHODOLOGY}

\subsection{Research Design}

The study used a quantitative correlational research which measure the relationship between two or more variables by using statistical correlation analysis (Creswell, 2014). This study analyzed whether or not there were the significant correlations among English learning anxiety, speaking, and writing achievements. 
Dian Eva Lestari, Bambang Loeneto and Diemroh Ihsan

\subsection{The Population and sample}

The population of the study was the eleventh graders' of SMA Srijaya Negara Palembang which consisted seven classes. The total number of the population were 242 students. The study used simple random sampling which determined all sample units in the specific population that have the same, equal, known chance of being selected. The sample were 112 samples which was chose based on Cochran (1977), the writer chose the sample size for $\pm 7 \%$ where confidence level is $95 \%$ and $p=.5$

\subsection{Research Instruments}

The researcher provided 3 instruments such as questionnaire, speaking, and writing tests.

Questionnaire

The researcher used ready made questionnaire by Horwits, Horwitz, and Cope (1986) to measure the students' English learning anxiety level. The questionnaire consisted 33 questions.

Speaking and Writing Tests

Giving speaking and writing tests were used to measure how well the students have mastered their speaking and writing achievements. In speaking test, the topic consisted of 3 topics. Then, the students presented one of the topics about the factual report text. The students talked about 1-3 minutes audio taped test of oral language ability. Then, the researcher would record the students' test. While in writing test, it also has 3 topics. The students wrote one of the topics. The results of speaking and writing tests were scored by two raters. To give the scores, the raters were guided by using rubric and range of score.

\subsection{The Techniques for Collecting The Data}

This study used questionnaire, speaking, and writing tests. The researcher conducted to the eleventh graders' of SMA Srijaya Negara Palembang in 2018/2019 academic year.

Questionnaire

The researcher used ready made questionnaires by Horwitz, Horwitz, and Cope (1986). Horwitz, Horwitz, and Cope's theory has provided valid and realible evidence. It also used in different language (Aydin et al., 2016)

Speaking and Writing Tests

In conducting speaking and writing tests, the researcher provided three topics about the factual report text. The researcher investigated speaking and writing tests by using the content validity and realibility of the tests. The researcher developed a table of specification to asses the content validity of the test. Heale and Twycross (2015) validity refers to the concept what it claims or suppose to be measured in a

Indonesian Journal of EFL and Linguistics, 4(2), 2019 
quantity study. Then, the researcher used realibility of the test by giving writing and speaking tests to obtain the students' speaking and writing achievements of the eleventh graders' of SMA Srijaya Negara Palembang. The writer conducted interrater method to measure the consistency of the text scored. According to Ninci et al. (2015) inter-rater realibility evaluates and makes decision which can be accepted or not for the tests. Inter-rater realibility were lecturers of Sriwijaya University. In the realibility coefficients of the test, the test must be at least 0,70 and preferebly higher. After the test were valid and realiable, the researcher gave the test to teh students to measure the students' speaking and writing achievements. A test is an instrument and a technique, procedure, or item that requires performance on the part of the test takers. By giving testing, the researcher can achieve the students' feedback from their performance (Wiklund, Jansson, and Nyberg, 2014). In speaking test, the study provided three topics. The students presented one of the topics about the factual report text for 1-3 minutes. During the test, the students would be recorded. While in writing test, the students also wrote one of the topics from 3 topics. The results of speaking and writing tests were scored by two raters. To give the scores, the raters were guided by using rubric and range of score.

\subsection{The Techniques for Analyzing The Data}

The reseacher analyzed the data by using questionnaire, speaking, and writing tests. First, the questionnaire consisted 33 questions with 5 point likert scale. The items consisted "strongly agree to strongly disagree". The response' items were "strongly disagree" $=1$, "disagree" $=2$, "neither agree or disagree" $=3$, "agree" $=4$, and "strongly agree" $=5$. The range scale of English learning anxiety was from 33-132 which were low (33-69), moderate (70-89), and high anxiety (90-132).

Second, the researcher used score interval to check the students writing and speking tests. In speaking test, the researcher used the score interval by Haris (1974). It consisted "very poor" $=0-20$, "poor" $=21-40$, "mediocre" $=41-60$, "good" $=61-80$, and "excellent" $=81-100$. While in writing test, the researcher used the score interval by Haris (1969) which was divided into "very poor"=5-29, "poor"=30-59,"fair"=6074,"good"=75-89,"excellent" $=90-100$. Moreover, the study also used Pearson Correlation to correlate among English learning anxiety, speaking, and writing achievements to find out whether there were the correlation among those variables. If the significance value ( $\mathrm{Sig} .2$ tailed) was less than alpha=0,05, it means that there is correlation between independent and dependent variables.

Finally, the study applied the regression analysis. To test whether variable $X$ (English learning anxiety) significantly determined variable Y (students' speaking and writing achievements)

\section{FINDINGS}

In this section, the students' speaking and writing achievements score will be statistically analyzed to measure the students' achievement. The questionnaire was 
Dian Eva Lestari, Bambang Loeneto and Diemroh Ihsan

analyzed to measure the students' English learning anxiety level. Then, the statictical analyses were used to find out whether or not there were correlation among English learning anxiety, speaking, and writing achievements.

\subsection{Writing Ability of Students}

To answer the research question whether or not there was correlation between English learning anxiety and writing achievement, the researcher calculated the means and the standard deviations. The researcher also calculated the minimum and maximum score to measure how the students have mastered in writing ability. Based on the diagram 1, the descriptive statistics showed the maximum score of writing ability was 85 and the minimum score was 20 . The mean and the standard deviation were 47.46 and 14.886. So, the students achieved low score in writing.

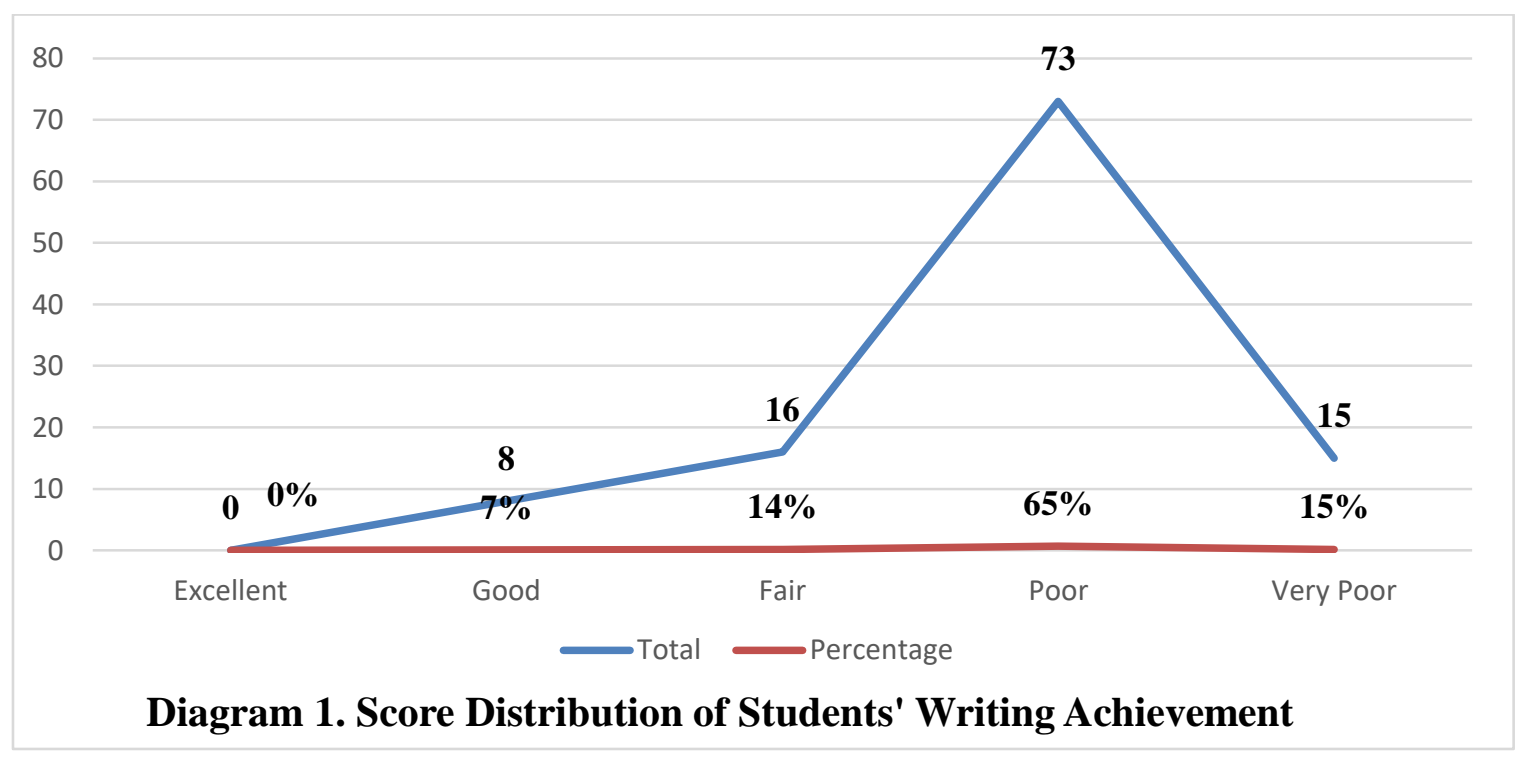

Diagram 1 showed the percentage scores of students' writing ability. The researcher divided into five level of writing ability such as very poor (5-29), poor (30-59), fair (60-74), good (75-89), and excellent (90-100). There were 15 (13\%) students who categorized as very poor, $73(65 \%)$ students as poor, $16(14 \%)$ students as fair, and 8 $(7 \%)$ students as good. The last, there was no student in excellent level.

\subsection{Speaking Ability of Students}

The descriptive statistics of speaking ability showed that the maximum score and minimum score were 86 and 20. The standard deviation and mean score were 14.022 and 47.70. The data from diagram 2 showed the percentage of the students' speaking ability. It was also divided into five categories of level achievement such as very poor (0-20), poor (21-40), mediacore (41-60), good (61-80), and excellent (81-100). There was no student in very poor level. There were $38(32 \%)$ categorized in poor 
level, $55(46 \%)$ categorized in mediacore, and $18(15 \%)$ categorized in good. The last, there was $1(1 \%)$ in excellent level.

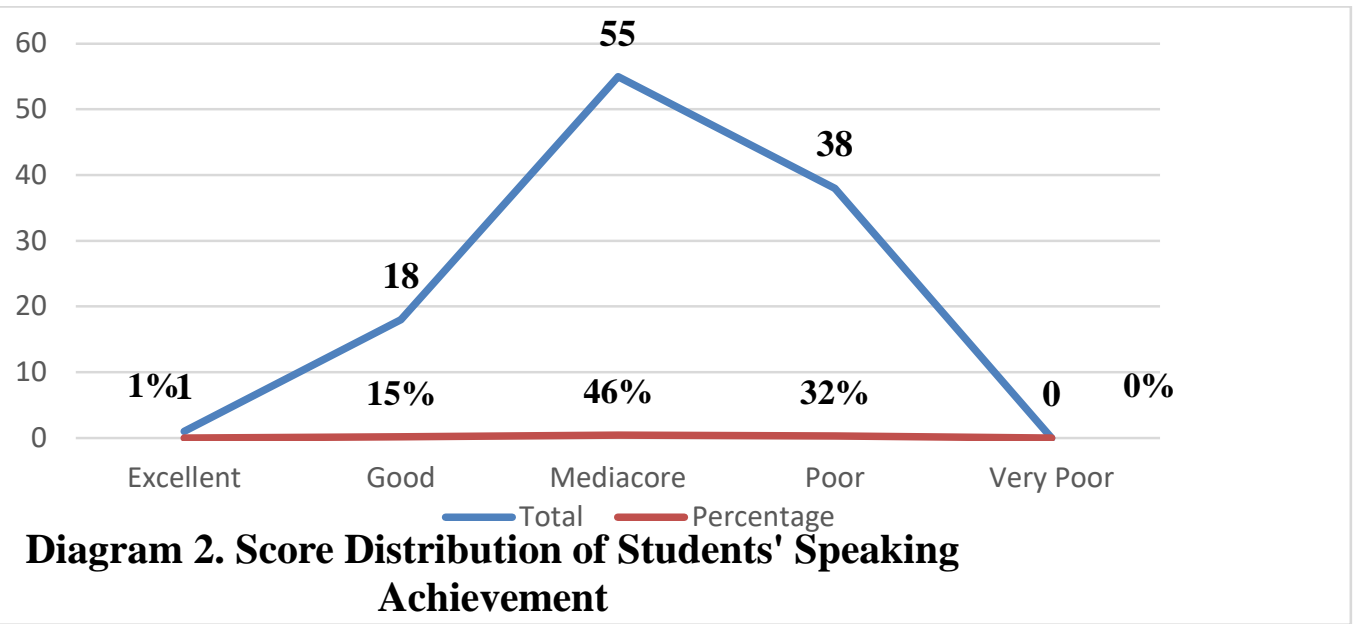

\subsection{English learning anxiety of Students}

The results of English learning anxiety achieved that the minimum score and maximum socre were 68 and 128. The standard deviation was 11.957.

Table 1. The Mean and Standard Deviation of English Learning Anxiety

\begin{tabular}{|c|c|c|c|c|c|c|c|}
\hline \multirow{2}{*}{ Items } & \multicolumn{4}{|c|}{ Percent (\%) } & Mean & $\begin{array}{c}\text { Std. } \\
\text { Deviation }\end{array}$ \\
\cline { 2 - 7 } & $\begin{array}{c}\text { Strongly } \\
\text { Disagree }\end{array}$ & Disagree & $\begin{array}{c}\text { Neither Agree } \\
\text { nor Disagree }\end{array}$ & Agree & $\begin{array}{c}\text { Strongly } \\
\text { Agree }\end{array}$ & & \\
\hline Item 31 & $4 \%$ & $15 \%$ & $64 \%$ & $13 \%$ & $3 \%$ & 2.97 & 0.77 \\
\hline Item 17 & $3 \%$ & $8 \%$ & $51 \%$ & $33 \%$ & $8 \%$ & 3.37 & 0.80 \\
\hline Item 15 & $2 \%$ & $9 \%$ & $38 \%$ & $34 \%$ & $17 \%$ & 3.55 & 0.93 \\
\hline Item 16 & $2 \%$ & $18 \%$ & $49 \%$ & $26 \%$ & $13 \%$ & 3.37 & 0.93 \\
\hline
\end{tabular}

Based on the results in table 1, the highest percentages of score in English learning anxiety were, "I never feel quite sure of myself when I am speaking in my foreign language class" 64\% which were "Neither Agree nor Disagree". The mean of the score was 2.97 and standard deviation was 0.77 . The students stated "I keep thinking that other students are better at language than I am" 51\% that were "Neither Agree nor Disagree". The mean of the score and the standard deviation were 3.37 and 0.80 .

Moreover, the lowest percentages in English learning anxiety were scored for the items "When I am on my way to language class, I feel very sure and relaxed" was "Strongly Disagree". The mean of the score was 3.55 and the standard deviation was 0.93. The students also stated "I feel overwhelmed by the number of rules you have 
to learn a foreign language" that both of items achieved $2 \%$ of the students. The students thought "Strongly Disagree". The mean of score and the standard deviation were 3.37 and 0.93 .

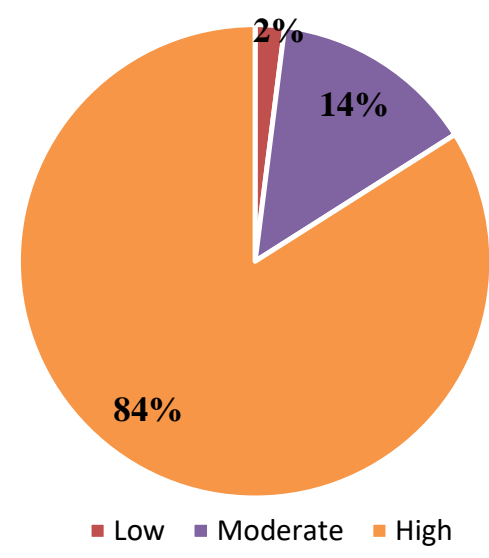

Diagram 3. The Students' English Learning Anxiety Level

The diagram 3 indicated that there were 94 (84\%) of teh students from $90-132$ in high level of anxiety, but there were 16 (14\%) students who got moderate level of anxiety from 70 to 89 , and $2(2 \%)$ students' lowest level of anxiety from 33 to 69 . The overall average of the mean scores of English learning anxiety was 3.08 and the standard deviation was 1.07 which was 94 (84\%) in high level of English learning anxiety. In conclusion, English learning anxiety can influence on the students' performance.

\subsection{Statistical Analyses}

\section{Normality, Homogenity, and Linerity Tests}

The results of Kolmogrov-Smirnov statistic test among English learning anxiety, speaking, and writing achievements were normal with significant value .118, 0.52, and 0.96 which were $p<0.05$. While the results of the homogenity and linerity tests achieved between English learning anxiety and speaking achievement were .98 and .627 and English learning anxiety and writing achievement were .54 and .627 with $\mathrm{p}<0.05$. In conclusion, the data were homogenious and linear.

\section{Research Questions 1 and 2 : Were any significant correlations among English learning anxiety, speaking, and writing achievements of the eleventh graders'?}

Table 2 showed that the correlation among English learning anxiety, speaking, and writing achievements were negative. The correlation coefficient were $r=.-269$ and .213 with significant value $\mathrm{p}<0.05$. The correlation among English learning anxiety, speaking, and writing achievements were low significant. 
The Correlation Among English Learning Anxiety, Speaking and Writing Achievements

Table 2. Correlation among English learning anxiety, Speaking, and Writing Achievements

\begin{tabular}{|c|c|c|}
\hline English learning anxiety & Speaking Achievement & Writing Achievement \\
\hline Pearson Correlation & -.269 &.-213 \\
Sig. (2-tailed) & .004 & 0.24 \\
$\mathrm{~N}$ & 112 & 112 \\
\hline
\end{tabular}

Considering some variables (speaking and writing achievement) could affect the students' English learning anxiety. In regression analysis, there were $4.5 \%$ of English learning anxiety effect to writing achievement and $7.2 \%$ to speaking achievement. It means when the students feel anxious. It can effect for their language learning ability and achievement.

Table 4. The Influence of English Learning Anxiety, Speaking, and Writing Achievements

\begin{tabular}{|l|c|c|c|c|}
\hline \multirow{2}{*}{ Model } & \multicolumn{4}{|c|}{ Change Statistics } \\
\cline { 2 - 5 } & $\mathrm{R}$ & R Square Change & F Change & Sig. F. Change \\
\hline Speaking Achievement & .269 & 0.72 & 8.558 & 0.04 \\
\hline Writing Achievement & .213 & 0.45 & 5.220 & 0.24 \\
\hline
\end{tabular}

\section{DISCUSSION}

English learning anxiety is an emotional and individual characteristic which has an important role and one of factors of element that hamper learning of foreign language. The present study found the correlation among English learning anxiety, speaking, and writing achievements that were negative and low significant correlation. It indicated that the students achieved facilitating and debilitating anxiety. It means that English learning anxiety can give positive and negative influences for the students' speaking and writing achievements. English learning anxiety drived the students to give better performance because the students got motivation to be better from others. The students were not always categorized as the bad students, but some of them were good with academic track record. The students felt anxious because they got experience from their friends that were not easy to achieve good scores from the class. However, some students who basically were smart. They also felt anxious and achieved low scores. It happened because they were not serious in following the subject, ignoring to write the subject, feeling lazy to study the subject. In fact, in speaking or writing class, the students are expected to more practice, add vocabulary, be careful with writing systems, and have good logic in expressing the ideas. The researcher also found the similirities research between findings and theories. Hartono (2012) investigated that 53 students of English Indonesian Journal of EFL and Linguistics, 4(2), 2019 
Department, Soegijapranata Catholic University, Semarang in 2011 achieved negative significant correlation between English learning anxiety and students' achievement. The findings of this study achieved negative low correlation among English learning anxiety, speaking, and writing achievements. It means that high level anxiety do not always achieve low scores. While, low anxiety level may achieve low scores. Those phenomenas may happen because the students have facilitating and debilitating anxiety. Horwitz (2017, as cited in Gknou, Daubney, and Dewale, 2017) reported that the correlation of negative versus positive can generate facilitating versus debilitating role of English learning anxiety. Facilitating anxiety means that English learning anxiety enhance the students' achievement. The English learning anxiety motivated the students to do more efficiently and encourage the efforts to overcome the feeling of English learning anxiety. The students improved the writing task and speaking performance. Selvam et al. (2016) believed that English learning anxiety is the significant role in giving motivation. The students wanted to learn more and give better performance from their failure. The finding of the study was moderate speaking anxiety. While debilitating anxiety gave bad results which block the students' learning process. The students felt more anxious, worry, and fear, and achieved low scores (Gerencheal, 2016). The students got problems in delivering spontanoeusly, making mistakes, low or uneven participation, and using mother tongue (Al Hosni, 2014). Rezaei and Jafari (2014) found the students' problems in writing such as deficiency and less practice in writing, fear in writing test, fear in getting negative feedback or comment, lack of knowledge, lack of vocabulary, tension indoing perfect work, time limit, and less self-confidence. According Kruk's (2018) investigated 52 Polish senior high school students by using questionnaire, interview, and lesson plan. The study found that English learning anxiety changed along semester either during class or from one language lesson to others.

Moreover, the highest results of questionnaires stated "Neither Agree nor Disagree". The statement were "I never feel quite sure of myself when I am speaking in my foreign language class" and "I keep thinking that other students are better at language" with "Neither Agree nor Disagree". The findings above were similarly with other theories. According Amiri and Putch (2018) reported that the students' negative attitudes played the significant role for the students' speaking achievement. English learning anxiety gave the role of unwelcoming interlocutors' attitude and judgmental view for the students' speaking achievement such as feeling afraid, making mistake, stress, and pressure (Hammad and Ghali, 2015). They felt reluctant to speak and had negatively impeding succesful communication. Similarly, Mahmud (2017) found that the students lack the confidence and performance. The lowest results stated that "I feel overwhelmed by the number of rules you have to learn a foreign language" that were "Strongly Disagree". Similarly, Ahmed, Pathen, and Khan (2017) also found that English learning anxiety can influence to the students' failure in using grammar. 
In conclusion, more studies are also needed to investigated the inteplay of various contributing variables as the exact relationship and may be influenced by various concomitant factors. For example, the studies apply in elementary school, junior high school, learners of language other than English (Marsden and Plonsky, 2017). Teimouri (2018) also hope future studies that examine others link. For example, other reseachers investigate the correlation English learning anxiety with others variables such as age, gender, fear, and etc.

\section{CONCLUSION}

This study investigated the correlation among English learning anxiety, speaking, and writing achievements that were negative and low significant correlations. It indicated that the students achieved facilitating and debilitating anxiety. In reducing English learning anxiety, the students are expected to do more practice, beyond some vocabulary, be careful with writing systems, have a good logic in expressing the ideas. Furthermore, further studies can investigate the inteplay of various contributing variables as the exact relationship and may be influenced by various concomitant factors.

\section{REFERENCES}

Ahmed, N., Pathan, Z. H., \& Khan, F. S. (2017). Exploring the causes of english language speaking anxiety among postgraduate students of university of balochistan, pakistan. International Journal of English Linguistics, 7(2), 99-105. doi:10.5539/ijel.v7n2p99

Albarai, F. (2015). The influence of teachers' anxiety-reducing strategies on learners' foreign language anxiety. Innovation in Language Learning and Teaching, 9(2), 163-190. doi: 10.1080/17501229.2014.890203

Al Hosni, S. (2014). Speaking difficulties encountered by young efl learners. International Journal on Studies in English Language and Literature, 2(6), 2230. Retrieved from https://www.researchgate.net/publication/270340628

Anwar, K., \& Iramawaty, L. (2015). Writing factual report: A potential way to enhance student's critical thinking ability. Jurnal Inovasi Pembelajaran, 1(2), 141-149. doi: 10.22219/jinop.vli2.2568

Amiri, F., \& Puteh, M. (2018). Oral communication apprehension among international doctoral students. English Language Teaching, 11(2), 164-171. doi:10.5539/elt.v11n2p164

Ariyanti, A. (2017). Foreign language anxiety in academic writing. Dinamika Ilmu, 17(1), 143-152. doi: 10.21093/di.v17il.815

Aydin, S., Harputlu, L., Guzel, S., Celik, S. S., Ustuk, O., \& Genc, D. (2016). A turkish version of foreign language anxiety scale: Reliability and validity. Procedia Social and Behavioral Sciences, 232, 250-256. doi: 10.1016/j.sbspro.2016.10.011 
Dian Eva Lestari, Bambang Loeneto and Diemroh Ihsan

Cochran, W. G. (1977). Sampling techniques: Chapter 5 ( $3^{\text {rd }}$ ed.). New York, NY : John Wiley and Sons, Inc. Retrieved from https://scholar.google.com .tr/scholar?q=sampling+techniques\&btnG=\&hl=en\&as_sdt=0,5\#0

Creswell, J. W. (2014). Research design: Qualitative, quantitative, and mixed methods approaches $\left(4^{\text {th }}\right.$ ed.). Thousand Oaks, CA: SAGE Publications, Inc.

Dar, M. F., \& Khan, I. (2015). Writing anxiety among public and private sectors pakistani undergraduate university students. Pakistani Journal of Gender Studies, 10, 121-136.

Dewale, J. M., \& Al-Saraj, T. M. (2015). Foreign language classroom anxiety of arab learners of english: The effect of personality, linguistic, and sociobiographical variables. Studies in Second Language Learning and Teaching, 5(2), 205-228. doi: 10.14746/ssllt.2015.5.2.2

Duraku, Z. H. (2017). Factors influencing test anxiety among university students. The European Journal of Social and Behavioural Sciences, 1(1), 2325-2334. doi: $10.15405 /$ jjsbs.206

Fitriati, S. W., \& Jannah, M. (2016). Psychological problems faced by the yeareleven students of ma muhad demak in speaking english. English Educational Journal, 6(1), 65-78.

Firmander, J. M., Gavin, M. K., \& McCoach, D. B. (2014). Examining the relationship between teachers' instructional practices and students' mathematics achievement. Journal of Advanced Academics, 25(3), 214-236. doi: $10.1177 / 1932202 \times 14538032$

Gilakjani, A. P. (2016). English pronunciation instruction: A literature review: International Journal of Research in English Education, 1(1), 1-6.

Gerencheal, B. (2016). Gender differences in foreign language anxiety at an ethiopian university: Mizan-tepi university third year english major students in focus. African Journal of Education and Practice, 1(1), 1-16.

Gknonou, C., Daubney, M., \& Dewale, J. M. (2017). New insights into language anxiety: Theory, research and educational implication. Bristol, UK : Multilingual Matters.

Hammad, E. A., \& Ghali, E. M. A. (2015). Speaking anxiety level of gaza efl preservice teachers. Reasons and sources. World Journal of English Language, 5(3), 52-64. doi: 10.5430/wjel.v5n3p52

Hartono, H. (2012). The correlation between students' level of anxiety and students' achievement in writing class. LITE: Jurnal Bahasa, Sastra, dan Budaya, 8(2), 106-112.

Heale, R., \& Twycross, A. (2015). Validity and reliability in quantitative studies. Evidence-Based Nursing, 18(3), 66-67. doi: 10.1136/eb-2015-102129

Horwitz, E. K., Horwitz, M. B., \& Cope, J. (1986). Foreign language classroom anxiety. The Modern Language Journal, 70(2), 125-132. https://doi.org/10.1111/j.1540-4781.1986.tb0526.x 
The Correlation Among English Learning Anxiety, Speaking and Writing Achievements

Kementrian Pendidikan dan Kebudayaan Republik Indonesia. (2016). Peraturan menteri pendidikan dan kebudayaan No. 22 Tahun 2016 tentang proses standar pendidikan dasar dan menengah. Peraturan Menteri Pendidikan dan Kebudayaan. Retrieved from http://bsnp-indonesia.org/wpcontent/uploads/2009/06/Permendikbud_Tahun2016_Nomor022_Lampiran.pdf

Kralova, Z. (2016). Foreign language anxiety. Retrieved from https://www.researchgate.net/publication/312918924_Foreign_Language_Anxie ty. Accessed on October 2019

Kruk, M. (2018). Changes in foreign language anxiety: A classroom perspective. International Journal of Applied Linguistics, 28(1), 31-57. doi: 10.1111/ijal.12182

Mahmud, M. (2017). Communication styles of english students at the state university of makassar. Gema Online Journal of Language Studies, 17(1). 223 238. doi: 10.17576/gema-2017-1701-13

Marsden, E., \& Plonsky, L. (2018). Conclusion: Data open science, and methodological reform in second language acquisition research. Language Learning and Language Teaching, 51, 1-18. doi: 10.1075/111t.51.10mar

Mukminin, A., Noprival., Masbirorotni, M., Sutarno., Arif, N., \& Maimunah. (2015). Efl speaking anxiety among senior high school students and policy recommendations. Journal of Education and Learning, 9(3), 217-225.

Nguyen, H. T., \& Tran, N. M. (2015). Factors affecting students' speaking performance at le thanh hien high school. Asian Journal of Educational Research, 3(2), 8-23.

Ninci, J., Vannest, K. J., Wilson, V., \& Zhang, N. (2015). Interrater agreement between visual analysts of single-case data: A meta-analysis. Behavior Modification, 39(4), 510-541. doi: 10.1177/0145445515581327

Rausch, P. (2015). The relationship between english speaking and writing proficiency and its implications for instruction, Master's thesis, St. Cloud State University, Minnesto, United States. Retrieved from https://repository.stcloudstate.edu/engl_etdsRecommended

Reddy, M. S. (2016). Importance of english language in today's world. International Journal of Academic Reserch, 3(4), 179-184.

Rezaei, M., \& Jafari, M. (2014). Investigating the levels, types, and causes of writing anxiety among iranian efl students: A mixed method design. Procedia Social and Behavioral Sciences, 98, 1545-1554. doi: 10.1016/j.sbspro.2014.03.577

Salehi, M., \& Marefat, F. (2014). The effects of foreign language anxiety and test anxiety on foreign language test performance. Theory and Prcatice in Language Studies, 4(5), 931-940. doi: 10.4304/tpls.4.5.931-940

Sayuri. (2016). English speaking problems of efl learners of mulawarman university. Indonesian Journal of EFL and Linguistics, 1(1), 47-61. doi: 10.21462/ijefl.v1i1.4 
Dian Eva Lestari, Bambang Loeneto and Diemroh Ihsan

Selvam, P., Syahida, E., Kemal, M. B., Swaminathan, V. N. G., \& Baskaran, S. (2016). Effects of debilitative and facilitative anxiety on speaking in second language among malaysian esl learners, 1-20.

Seyitoglu, F., Guven, A., \& Kocabulut, O. (2015). Effects of intercultural communcation apprehension on satisfaction on foreign students. Proceedings of the First European Academic Research Conference on Global Business, Economics, Finance and Social Science, 1-12

Teimouri, Y. (2016). Differential roles of shame and guilt in 12 learning: How bad is bad? Modern Language Journal, 102(4), 1-21. doi: 10.1111/modl.12511

Wiklund, H. C., Jonsson, B., \& Nyberg, L. (2014). Strengthening concept learning by repeated testing. Scandinavian Journal of Psychology, 55(1), 10-16. doi: 10.1111/sjop.12093

Younez, Z. B., \& Albalawi, F. S. (2015). Exploring the most common types of writing problems among english language and translation major sophomore femal students at tabuk university. Asian Journal of Basic and Applied Sciences, 3(2), 7-26. Retrieved from www.multidisciplinary.journals.com 